\title{
Fatal migration of an endobronchial stent into the pulmonary artery
}

\author{
Till Plönes, Aris Koryllos, Frank Beckers, Erich Stoelben
}

University Medical Center Witten/Herdecke, Köln, Germany

Correspondence to Dr Till Plönes,

Till_ploenes@gmx.de

\section{DESCRIPTION}

A 64-year-old woman was referred to our department with progressive dyspnoea and haemoptysis. Half a year ago a metallic endobronchial stent was inserted in the left main bronchus due to a benign stenosis after sleeve resection for lung cancer. A CT showed the stent with erosion of the left pulmonary artery and newly diagnosed pulmonary metastasis (figure 1). We decided to perform a palliative pneumonectomy for symptom control. Intraoperative findings confirmed the migration of the endobronchial stent through the bronchial wall to the left pulmonary artery (figure 2). Unfortunately, the patient died intraoperatively due to an uncontrollable bleeding. However, endobronchial stenting is a well-

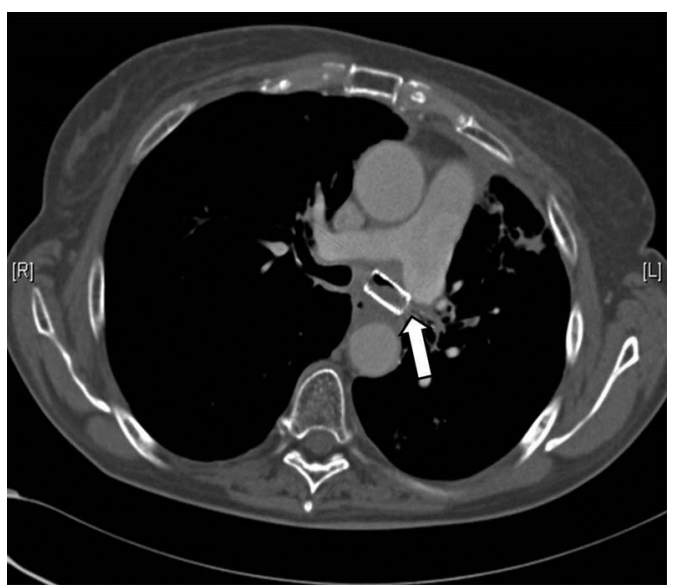

Figure $1 \mathrm{CT}$ of the chest showing the endobronchial stent (white arrow) transecting the left pulmonary artery.

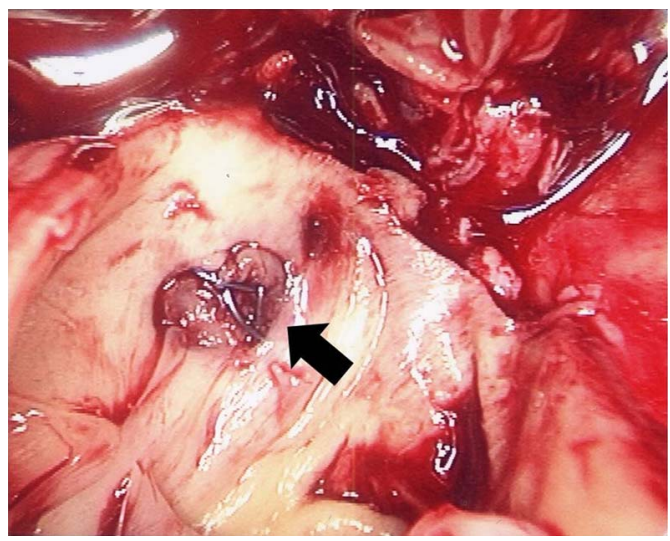

Figure 2 Intraoperative situs showing the metallic endobronchial stent (black arrow) eroding the bronchial wall into the pulmonary artery. established procedure in the management of benign or malign pathologies causing central airway obstruction, ${ }^{1}$ and endobronchial stents can be placed safely under general anaesthesia by rigid bronchoscopy. Since the development of airway stents in the 1960s, the use of airway stents increased rapidly, but too little is known about major complications. ${ }^{2}$ Especially in benign airway stenosis, the long-term placement of airway stents provides an underestimated risk. ${ }^{3}$ Fatal complications including migration of airway stents in the aorta, pulmonary artery or other important anatomic structures are reported only anecdotally, but occur probably more frequently than reported.

\section{Learning points}

- Especially in case of benign stenosis long-term placement of airway stents can result in serious complications like penetration of the stent in other anatomic structures. Therefore a careful evaluation of other treatment options is mandatory.

- If there is an indication for placement of an airway stent, it should be performed only by experienced and trained physicians.

- Close follow-up and permanent re-evaluation of the indication has to be performed to avoid migration of stents in important anatomic structures.

Contributors PT was involved in writing the manuscript. KA contributed by formatting the images. BF and SE reviewed the manuscript and made the final changes.

\section{Competing interests None.}

Patient consent Obtained.

Provenance and peer review Not commissioned; externally peer reviewed.

\section{REFERENCES}

1 Ranu H, Madden BP. Endobronchial stenting in the management of large airway pathology. Postgrad Med J 2009;85:682-7.

2 Dooms C, De Keukeleire T, Janssens A, et al. Performance of fully covered self-expanding metallic stents in benign airway strictures. Respiration 2009;77:420-6.

3 US Food and Drug Administration: metallic tracheal stents in patients with benign airway disorders. MedWatch The FDA Safety Information and Adverse Event Reporting Program 2005; http:/l www.fda.gov/Safety/MedWatch/Safetylnformation/ SafetyAlertsforHumanMedicalProducts/ucm 153009.htm 
Copyright 2013 BMJ Publishing Group. All rights reserved. For permission to reuse any of this content visit http://group.bmj.com/group/rights-licensing/permissions.

BMJ Case Report Fellows may re-use this article for personal use and teaching without any further permission.

Become a Fellow of BMJ Case Reports today and you can:

- Submit as many cases as you like

- Enjoy fast sympathetic peer review and rapid publication of accepted articles

- Access all the published articles

- Re-use any of the published material for personal use and teaching without further permission

For information on Institutional Fellowships contact consortiasales@bmjgroup.com

Visit casereports.bmj.com for more articles like this and to become a Fellow 